\title{
CONTROL OF SOME SOIL BORNE PATHOGENIC FUNGI IN SOYBEAN PLANT BY BIOFUMIGATION WITH MUSTARD SEED MEAL
}

Fayzalla, E.A. ${ }^{1}$; Ebtehag SH. H. El-Barougy ${ }^{2}$ and M.M.El-Rayes ${ }^{2}$

1- Plant Pathology Dep. Fac. of Agric. Mansoura Univ., Egypt

2-Plant Pathology Res. Inst., Agric. Res. Center, Cairo, Egypt

\begin{abstract}
Fusarium oxysporum (Schlecht Nedan); Rhizoctonia solani (Kuhn), Macrophomina phaseolina (Tassi) and Sclerotium rolfsii are found to be pathogenic to soybean causing damping off, root rot and wilt diseases resulting in serious economic losses. Biofumigation is used as a means to control many diseases by biocidal compounds (mainly isothiocyanates) released from glucosinolates in mustard seed meal is hydrolyzed during incorporation in the soil.

Laboratory, pots and field experiments were conducted to evaluate the efficacy of mustard (Brassica juncea (L.) seed meal on control by soil borne pathogens.

In laboratory experiments, mustard seed meal decreased the linear growth of the tested fungi as compared with the control.

The fungicidal effect of mustard seed meal against the tested fungi was demonstrated in pot experiments: diseases were suppressed and plant growth was increased compared to untreated (control). Similar control effect was also obtained in filed experiment conducted in Ismailia, Agric. Res. Station. The obtained results indicated that mustard seed meal reduced the disease incidence over control by $69.7 \%$ when recorded 4 months after planting. On the other hand, the reduction reached $74.4 \%$ over control by Rhizolex treatments when recorded 4 months after planting.

Keywords: soybean, biofumigation, mustard, Brassica juncea, isothiocyanates Fusarium, Rhizoctonia solani, Macrophomina phaseolina and Sclerotium rolfsii
\end{abstract}

\section{INTRODUCTION}

Soybean \{Glycine max (L.) Merr\} has many benefits for human and animal nutrition. It can be considered as a friendly crop to the environment related to its efficient nitrogen fixation system, in addition to its improvement to the traditional cereal rotation and protein supply in low input farming systems (Nassiuma and Wasike, 2002; Akande et al., 2007).

Soil-borne fungal diseases are among the most important factors limiting the yield production of grain legumes in many countries, resulting in serious economic losses. Pathogens such as F. oxysporum, R. solani, $M$. phaseolina and S. rolfsii affected the growth of Soyabean plants (Amer, 2005; Hashem, 2004; Luiz et al., 2006; Wrather et al., 2007; Haikal, 2008 and Sweets, 2008). These pathogens are difficult to control because of their persistence in the soil and wide host range. Some Chemicals are effective in controlling these diseases but, these chemicals are expensive and not environmental friendly. Therefore, alternative control methods are needed for managing these pathogens. Several alternative measures are being tested, including biofumigation. The suppressive effects of biofumigation are generally attributed to biocidal compounds, principally isothiocyanates (ITCs) 
released when the glucosinolates in Brassica species tissues are hydrolyzed in the soil (Sarwar et al., 1998; Olivier et al., 1999). These isothiocyanates have been shown previously to be fungicidal (Mazzola, 2003 and Kirkegaard et al., 2006). Several studies have shown that amending the soil with Brassica spp as seed meal suppressed many plant fungal pathogens. Charron \& Sams (1999); Mawar \& Lodha (2002) and Lodha \& Sharma (2002) studied the effect of amending the soil with Brassica spp crops on reducing the disease incidence or inoculum level of M.phaseolina, F.oxysporum and $R$. solani. Mazzola and Abi Ghanem (2006) evaluated the efficacy of brassicaceae seed meal amendments for control of the soil borne pathogen/parasite complex inciting apple replant disease, and the capacity of such treatments to enhance tree growth and yield. Van Os et al. 2004 \& Van Os and Lazzeri (2006) reported that in soil infested with $R$. solani, application of mustard seed meal resulted in significant control of stem infection in lily. Also, they proved that the efficacy of comparable to the chemical treatment with azoxystrobine. Robert and Timothy (2007)have shown that Brassica crops used as green manures have been associated with reductions in soil borne pathogens. These reductions have been attributed to the production of volatile compounds through a process known as biofumigation.

The objectives of the present study aimed to evaluate the efficacy of mustard seed meal as biofumigation for controlling damping off, root rot and wilt of soybean plants under laboratory, Pot and field conditions.

\section{MATERIALS AND METHODS}

\section{Samples collection, isolation and identification:}

Soybean plants showing root rot and wilt symptoms were collected from different localities of Ismailia Governorate. Ten plants (Two from the center and two near each corner) were removed from each field. Root rotted samples were first washed in running tap water to remove the adhering soil particles and then surface sterilized in $5 \%$ sodium hypochlorite solution for two minutes. The sterilized plant parts were rinsed several times in sterilized distilled water and dried between sterilized filter paper then cut into small pieces and directly placed on potato-dextrose agar medium (PDA) in Petridishes. The Petri dishes were incubated at $25^{\circ} \mathrm{C}$ for 5-7 days. The hyphal tips of the growing hyphae were taken from the growing colonies and transferred to PDA plates and purified using single-spore technique as described by Toussoun and Nelson (1968). Isolated fungi were identified according to their morphological characters according to Booth (1971), Nelson et al. (1983) and Barnett and Hunter (1986).

Effect of mustard (Brassica juncea) on controlling some soil borne pathogens of soybean plants:

1-Laboratory experiments:

1.1- In vitro: effect of mustard seed meal on linear growth of soybean root-rot and wilt fungal pathogens in vitro:

Four soil-borne fungal pathogens (F.oxysporum, R.solani, M. phasolina and Sclerotium rolfsii ) previously isolated as mention before from soybean diseased plants. Five $\mathrm{mm}$ discs of actively growing mycelium were taken from 
the margins of fungal growth and transferred to Petri dishes $(9 \mathrm{~cm}$ in diameter) containing PDA supplemented with 150 ppm streptomycin. Fresh seed of Mustard (B. juncea) was ground in a food processor for about 2 min, the ground seed meal was placed in $5 \mathrm{~cm}$ Petri dish onto the upturned lid of the plates with the inverted bottom containing the fungal plug as the lid. Sterile distilled water at a rate $1: 2(\mathrm{w} / \mathrm{v})$ was added to the meal to release the isothiocyanates (ITCs) and the plate was immediately sealed with parafilm. The rates of seed meal used were 0 (control), 5, 10 and $25 \mathrm{mg}$ and duplicate plates of each rate were prepared. Seed meal free PDA medium was used as control treatment. The plates were incubated at $25^{\circ} \mathrm{C}$ for 5 days, after which time the colony diameter was measured for each treatment, the pathogenic fungi almost covered the medium surface in control treatment

1.2-Effects of mustard seed meal on soybean germination and growth:

In this experiment soil collected from Ismailia Agric. Res. Station was packed into plastic pots $12 \mathrm{~cm}$ in diameter and $15 \mathrm{~cm}$ high contaning the mustard seed meal was applied to five replicate pots at rates of 0 (control), $0.113,0.226,0.565,1.130 \mathrm{~g} /$ pot. Soybean seeds were sown in the pots (10 per pot) at a depth of $1 \mathrm{~cm}$ immediately following application of the mustard meal. The pots were watered throughout the experiment. Seed germination\%: time to emergence (days) was recorded, and 30 days after seeding, the plants were harvested for measurement the plant height and shoot weight.

\section{2 -Pots experiment:}

Pots experiment was carried out at Ismailia Agric. Res. Station to evaluate the efficiency of mustard seed meal comparing with Rhizolex ${ }^{\circledR}$ in controlling some soil borne diseases in soybean

Preparation of fungal inoculum for soil infestation was carried out as following:

Sterilized sorghum medium inoculated with the tested fungi and incubated at $25^{\circ} \mathrm{C}$ for 15 days. Pots $(30 \mathrm{~cm}$ in diam.) containing with unsterilized soil were simply infested with each of the tested fungi ( $F$. oxysporum, R.solani, M.phaseolina and S. rolfsii) at the rate of $3 \%(\mathrm{~W} / \mathrm{W})$ of soil weight. The infested soil was watered and mixed thoroughly for one week to insure even distribution of the inoculum.

Four treatments were performed in four replicates including:

1-A non-infested soil treatment (control 1)

2-An infested soil treatment (control 2)

3- Infested soil + mustard seed meal. The meal (3.5g/pot) was mixed through the pot soil at depth of $2 \mathrm{~cm}$ and watered.

4- Infested soil + Rhizolex ${ }^{\circledR}(50 \mathrm{ml} /$ pot at rate of $1.5 \mathrm{~g} / \mathrm{l}$, mixed through the soil prior to planting)

A set of 4 pots for each treatment were cultivated by 10 soybean seeds Giza $35 \mathrm{cv} /$ pot. Percentage of damping off and percentage of survived plants (healthy and infected) were recorded 30 and 90 days after planting, respectively. Infected survival plants were evaluated 3 months after seeding by cutting longitudinally through each plant (stem and root) and any discoloration of internal tissue was recorded. Healthy survival plants $=$ no visual evidence of disease. Plant growth parameters (Shoot weight, plant 
Fayzalla, E.A. et al.

height/plant (aver. of 5 plants ) were recorded four months after planting. Disease severity indexing (DSI) of root rot and any discoloration of tissue were recorded according to based on $0-4$ scale according percentage of foliage yellowing or necrosis Haware and Nene (1980) based on ( $0=0 \%, 1=1$ $33 \%, 2=34-66 \%, 3=67-100 \%, 4=$ dead plant )

\section{3-Field experiments:}

3.1 Effect of mustard seed meal and fungicide (Rhizolex ${ }^{\circledR}$ ) in disease control under field condition:

This experiment was conducted at Ismailia Agric. Res. Station to evaluate the efficiency of mustard seed meal for controlling root rot and wilt diseases complex of soybean. Treatments were arranged in a complete randomized block design with four replicates. The field plot was $3 \times 3 \mathrm{~m}$ with 5 rows. These treatments were as follows:

1. Control (No treatments).

2. Mustard seed meal (The meal can be applied to the plot soil at rate of $5 \mathrm{~g} / \mathrm{m}^{2}$ at sowing).

3. Rhizolex ${ }^{\circledR}$, mixed through the soil prior to planting.

Incidence (\%) of diseased plants (Total number of dead plants/ Total number of plants at plots) was calculated 4 months after planting.

Statistical analysis:

All the data were statistically processed by the analysis of variance and by determining the significance threshold using Duncan's test (Duncan, 1955).

\section{RESULTS}

\section{Isolation and identification of the causal pathogen:}

Isolation trails from rotted and wilted soybean plants collected from different localities of Ismailia Governorate yielded some fungi which were identified as Fusarium oxysporum, Rhizoctonia .solani, Macrophomina phaseolina and Sclerotium rolfsii.

Effect of mustard seed meal on some pathogenic fungi development in soybean plants:

1-Laboratory experiments:

1.1-In vitro: effect of mustard seed meal on linear growth of soybean root-rot and wilt fungal pathogens.

The effect of different levels of mustard seed meal on the linear growth of fungal pathogens tested is shown in Table (1). There were differences in the sensitivity of the pathogens to the seed meal at all levels with R.solani being the most sensitive fungus. The lowest value of linear growth $(3.8,1.2$ and 0.7 $\mathrm{cm}$ ) recorded with R.solani at $5 \mathrm{mg}, 10 \mathrm{mg}$, and $25 \mathrm{mg}$ of seed meal, respectively. The highest value of linear growth $(5.2 ; 4$ and $3.3 \mathrm{~cm})$ was obtained from $S$. rolfsii at $5 \mathrm{mg}, 10 \mathrm{mg}$, and $25 \mathrm{mg}$ of seed meal, respectively. Data also reveal that the effect of mustard seed meal on mycelial growth of the pathogens was proportional to the quantity of ground seeds. Significant differences were observed among with the different amount of seed meal for each fungus (Table 1). 
Table (1): Effect of mustard seed meal on mycelium growth in some pathogenic fungi of soybean

\begin{tabular}{|l|c|c|c|c|c|c|c|c|}
\hline \multirow{2}{*}{$\begin{array}{c}\text { Rate } \\
\text { of meal } \\
\text { in } \mathbf{~ m g}\end{array}$} & \multicolumn{2}{|c|}{$\begin{array}{c}\text { Fusarium } \\
\text { oxysporum }\end{array}$} & \multicolumn{2}{|c|}{$\begin{array}{c}\text { Rhizoctonia } \\
\text { solani }\end{array}$} & $\begin{array}{c}\text { Macrophomina } \\
\text { phaseolina }\end{array}$ & \multicolumn{2}{c|}{$\begin{array}{c}\text { Sclerotum } \\
\text { rolfsii }\end{array}$} \\
\cline { 2 - 9 } & $\begin{array}{c}\text { Linear } \\
\text { growth } \\
\text { (cm) }\end{array}$ & R. & $\begin{array}{c}\text { Linear } \\
\text { growth } \\
\text { (cm) }\end{array}$ & R. & $\begin{array}{c}\text { Linear } \\
\text { growth } \\
\text { (cm) }\end{array}$ & R. & $\begin{array}{c}\text { Linear } \\
\text { growth } \\
\text { (cm) }\end{array}$ & R. \\
\hline 5 & $4.1 \mathrm{~b}$ & 54.4 & $3.8 \mathrm{~b}$ & 57.7 & $4.5 \mathrm{~b}$ & 50 & $5.2 \mathrm{~b}$ & 42.2 \\
\hline 10 & $3.8 \mathrm{c}$ & 57.7 & $1.2 \mathrm{c}$ & 86.6 & $2.13 \mathrm{c}$ & 76.6 & $4 \mathrm{c}$ & 55.5 \\
\hline 25 & $2.1 \mathrm{c}$ & 76.6 & $0.7 \mathrm{~d}$ & 92.2 & $1.3 \mathrm{~d}$ & 85.5 & $3.3 \mathrm{~d}$ & 63.3 \\
\hline O(Control) & $9 \mathrm{a}$ & - & $9 \mathrm{a}$ & - & $9 \mathrm{a}$ & - & $9 \mathrm{a}$ & - \\
\hline L.S.D & 1.18 & & 0.79 & & 0.79 & & 1.03 & \\
\hline
\end{tabular}

Figures in the same column followed by the same letters are not significantly different $(p>$ 0.05 ) based on Duncan's multiple range test

$\mathbf{R}=$ reduction over control \%

1.2-Effects of mustard seed meal on soybean germination and growth:

The effect of mustard seed meal at the rate of $0.113,0.226,0.565$, $1.130 \mathrm{~g} /$ pot $(12 \mathrm{~cm}$ in diam.) on seed soybean germination and growth was shown in Table (2). Data reveal that mustard meal banded with soybean seed had no effect on soybean germination at the rate of 0.113 and $0.226 \mathrm{~g} / \mathrm{pot}$ compared with control treatment. At rate of $0.226,0.565 \mathrm{~g} /$ pot emergence time was delayed by 1 and 2.5 days, respectively but shoot weight and plant height were not reduced. The highest rate $1.13 \mathrm{~g} /$ pot delayed emergence time by 4 days and seed germination\%, shoot weight, plant height $(61.2 \%$, $4.3 \mathrm{~g}$, and $15.25 \mathrm{~cm}$ respectively) reduced comparing with control treatment ( $95 \%$ and $7.9 \mathrm{~g}$ and $21.3 \mathrm{~cm}$, respectively) (Table 2) deleterious effects were experiences at higher doses into all parameters tested.

Table 2. Effect of mustard seed meal on days to emergence (DTE); Seed germination \% and shoot weight, shoot height of soybean seedlings.

\begin{tabular}{|l|c|c|c|c|}
\hline \multicolumn{3}{|c|}{ Parameters growth } & \\
\cline { 1 - 4 } Rate (g/pot) & $\begin{array}{c}\text { Time to emergence } \\
\text { (days) }\end{array}$ & $\begin{array}{c}\text { Seed germination } \\
\%\end{array}$ & $\begin{array}{c}\text { Shoot weight } \\
\text { (g) }\end{array}$ & $\begin{array}{c}\text { Shoot height } \\
\text { (cm) }\end{array}$ \\
\cline { 1 - 4 } $\mathbf{0}$ (control) & 6 & $95 \mathrm{a}$ & $7.9 \mathrm{ab}$ & $21.3 \mathrm{~b}$ \\
\hline $\mathbf{0 . 1 1 3}$ & 6 & $95 \mathrm{a}$ & $7.1 \mathrm{~b}$ & $18.2 \mathrm{c}$ \\
\hline $\mathbf{0 . 2 2 6}$ & 7 & $95 \mathrm{a}$ & $8.9 \mathrm{a}$ & $24.5 \mathrm{a}$ \\
\hline $\mathbf{0 . 5 6 5}$ & 8.5 & $87.5 \mathrm{a}$ & $7.2 \mathrm{~b}$ & $19.25 \mathrm{c}$ \\
\hline $\mathbf{1 . 1 3}$ & 10 & $61.2 \mathrm{~b}$ & $4.3 \mathrm{c}$ & $15.25 \mathrm{~d}$ \\
\hline LSD & & 16.5 & 1.57 & 2.8 \\
\hline
\end{tabular}

Figures in the same column followed by the same letters are not significantly different $(p>$ 0.05 ) based on Duncan's multiple range test

\section{2 -Pot experiment:}

Effect of mustard seed meal and Rhizolex fungicide on damping off and survived soybean seedlings grown in soil infested with some pathogenic fungi:

Mustard seed meal and Rhizolex fungicide reduced significantly the infection effect of F.oxysporum , R.solani; M.phaseolina and S. rolfsii (Table3) and illustrated by Figs.(1). Percentage of healthy soybean survival plants 
Fayzalla, E.A. et al.

increased over the control No.1 (non treated infested soil). On the other hand, differences in the effect of mustard and the fungicide on the tested fungal pathogens were noted.

Data also indicate that soil infested with $F$. oxysporum used as control, showed the highest percentage of pre emergence damping off $(42.5 \%)$ followed by artificially infested soil treated with Rhizolex, and mustard seed meal (22.5\% 17.5\%respectively) Significant differences were realized between control No.1 (infested soil), and the other treatments; however, no significant differences were observed between Rhizolex, and mustard seed meal treatment

In soil infested with R.solani, data reveal that the percentage of pre emergence damping off, averaged $72.5 \%$ compared to $30 \%$ in artificially infested soil treated with both of Rhizolex, and mustard seed meal. .For post emergence damping off, the control recorded the highest percentage of infected plants (12.5) but the lowest percentage which reached $2.5 \%$ was obtained from mustard seed meal treatment followed by Rhizolex being 7.5. Concerning the percentage of healthy plants, the most effective treatment was mustard seed meal mixed with soil artificially infested with the pathogen at $(65 \%)$; however Rhizolex showed $57.5 \%$ while the control showed $15 \%$ survival.

Also, when mustard seed meal and Rhizolex used to control M.phaseolina resulted in the highest percentage of healthy plants $(57.5 \%$ and $52.5 \%$, respectively) comparing with the lowest percentage (17.5\%) obtained from the control treatment. For soil infested with S.rolfsii used as a control, the results showed that the lowest percentage of healthy plants $(25 \%)$.Whereas, the highest percentages (55\%) were obtained with Rhizolex treatment followed by mustard seed meal $(45 \%)$.

Table (3): Effect of mustard seed meal, and one fungicide on damping off, infected plants, healthy plants of soybean seedling infected with some pathogenic fungi

\begin{tabular}{|c|c|c|c|c|c|c|c|c|c|c|c|c|c|c|c|c|}
\hline \multirow{4}{*}{ Treatments } & \multicolumn{16}{|c|}{ Tested fungi } \\
\hline & \multicolumn{4}{|c|}{ Fusarium oxysporum } & \multicolumn{4}{|c|}{ Rhizoctonia solani } & \multicolumn{4}{|c|}{$\begin{array}{c}\text { Macrophomina } \\
\text { phaseolina }\end{array}$} & \multicolumn{4}{|c|}{ Sclerotum rolfsii } \\
\hline & \multicolumn{2}{|c|}{$\begin{array}{c}\text { Damping } \\
\text { off } \%\end{array}$} & \multicolumn{2}{|c|}{$\begin{array}{l}\text { Survival } \\
\text { Plant \% }\end{array}$} & \multicolumn{2}{|c|}{$\begin{array}{c}\text { Damping } \\
\text { off } \%\end{array}$} & \multicolumn{2}{|c|}{\begin{tabular}{|l|} 
Survival \\
Plant \%
\end{tabular}} & \multicolumn{2}{|c|}{$\begin{array}{c}\text { Damping } \\
\text { off } \%\end{array}$} & \multicolumn{2}{|c|}{\begin{tabular}{|l|} 
Survival \\
Plant \%
\end{tabular}} & \multicolumn{2}{|c|}{$\begin{array}{c}\text { Damping } \\
\text { off } \%\end{array}$} & \multicolumn{2}{|c|}{$\begin{array}{l}\text { Survival } \\
\text { Plant \% }\end{array}$} \\
\hline & pre & post & I & $\mathbf{H}$ & pre & post & I & $\mathrm{H}$ & pre & post & I & $\mathbf{H}$ & pre & post & I & $\mathbf{H}$ \\
\hline $\begin{array}{l}\text { Mustard } \\
\text { seed } \\
\text { meal }\end{array}$ & $17.5 b$ & $7.5 \mathrm{a}$ & $12.5 b$ & $62.5 \mathrm{v}$ & $30 b$ & $2.5 a$ & $2.5 \mathrm{a}$ & $65 b$ & $35 \mathrm{v}$ & $7.5 a$ & $5 a$ & $52.5 b$ & $35 b$ & $12.5 \mathrm{a}$ & $7.5 a$ & $45 b$ \\
\hline Rhizolex ${ }^{\circledR}$ & $22.5 \mathrm{~b}$ & $5 a b$ & $12.5 \mathrm{~b}$ & $60 \mathrm{~b}$ & $30 \mathrm{~b}$ & $7.5 \mathrm{a}$ & $5 a$ & $57.5 \mathrm{~b}$ & $30 b$ & $2.5 a$ & $10 \mathrm{a}$ & $57.5 b$ & $32.5 b$ & $10 a$ & $2.5 \mathrm{a}$ & $55 b$ \\
\hline \begin{tabular}{|l|} 
Infested soil \\
(Control1)
\end{tabular} & $42.5 \mathrm{a}$ & $10 a$ & $\begin{array}{c}22.5 \\
a\end{array}$ & $25 c$ & $72.5 a$ & $12.5 a$ & $0 a$ & $15 \mathrm{c}$ & $60 a$ & $15 a$ & $7.5 a$ & $17.5 \mathrm{c}$ & $65 a$ & $5 a$ & $5 a$ & $25 d$ \\
\hline \begin{tabular}{|l|}
$\begin{array}{l}\text { Non-infested } \\
\text { soil } \\
\text { (control2) }\end{array}$ \\
\end{tabular} & $5 c$ & $0 b$ & $5 a b$ & $90 \mathrm{~s}$ & $5 c$ & $0 \mathrm{a}$ & $5 a$ & $90 a$ & $5 c$ & $0 \mathrm{a}$ & $5 a$ & $90 a$ & $2.5 \mathrm{c}$ & $0 \mathrm{a}$ & $7.5 \mathrm{a}$ & $90 a$ \\
\hline LS D & \begin{tabular}{|l|}
11.9 \\
\end{tabular} & 6.6 & 8.61 & 8.61 & 13.5 & \begin{tabular}{|l|}
6.67 \\
\end{tabular} & \begin{tabular}{|l|}
7.37 \\
\end{tabular} & 11.55 & 14.8 & 12.33 & 11.5 & 4.16 & 15.4 & 13.8 & 10.91 & 11.26 \\
\hline
\end{tabular}




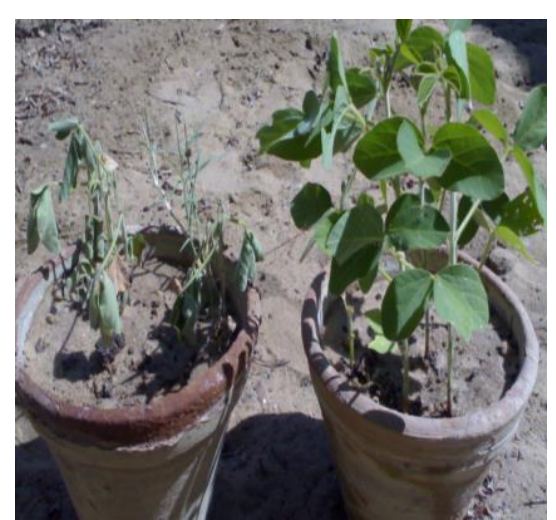

$\mathrm{F}$

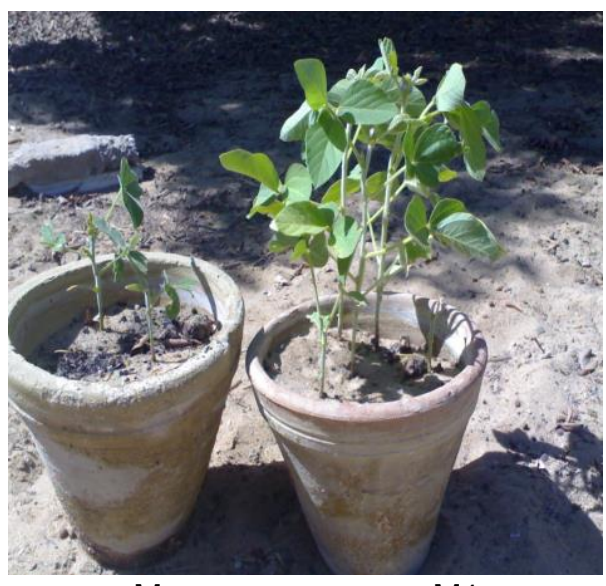

M
F1

$\mathrm{M1}$

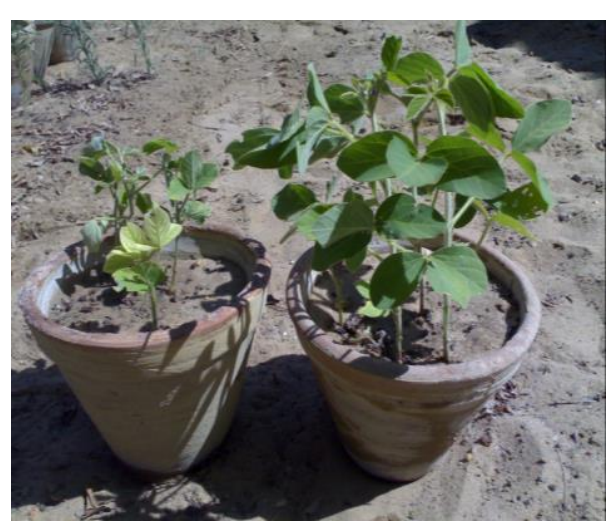

R1

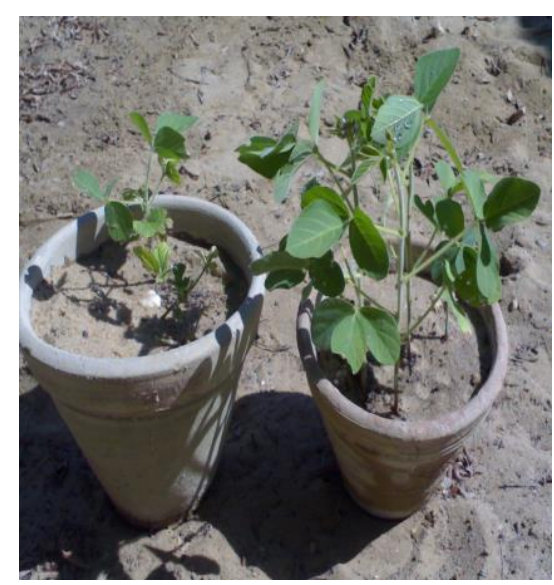

S

S1

Fig (1): Effect of mustard seed meal on some soil borne pathogenic fungi in soybean plants

$F=$ infested Soil with F.oxysporum

$\mathrm{Fi}=$ infested Soil with F.oxysporum + mustard seed meal.

$\mathbf{R}=$ infested Soil with R.solani

R1 = infested Soil with R.solani + mustard seed meal.

M = infested Soil with M.phaseolina

M1 = infested Soil with M.phaseolina + mustard seed meal

$\mathrm{S}=$ infested Soil with S.rolfsii

S1 = infested Soil with S.rolfsii + mustard seed meal

Effect of mustard seed meal, and one fungicide on Severity of disease reaction of soybean seedling infected with some pathogenic fungi:

Disease severity was recorded in Table ( 4 ), data revealed that soil infested with R.solani used as a control show the highest degree of disease severity (4.1) followed by, M.phaseolina, S. rolfsii and F. oxysporum which recorded 3.8, 3.6 and 2.9 respectively compared with the lowest one (1.07) recorded from non-infested soil (control2).Significantly differences were realized between control1 (infested soil) and other treatments, the most effective treatments were obtained from mustard seed meal except fungicide 
Fayzalla, E.A. et al.

Rhizolex when used to control R.solani resulted in the lowest value (1.6) comparing with the highest ( 4.1 )obtained from the control treatment.

Table (4): Effect of mustard seed meal, and one fungicide on Severity of disease reaction of soybean seedling infected with some pathogenic fungi

\begin{tabular}{|l|c|c|c|c|}
\hline \multirow{2}{*}{} & \multicolumn{4}{|c|}{ Tested fungi } \\
\cline { 2 - 5 } & \multicolumn{3}{|c|}{ Disease severity score ${ }^{\star \star}$} \\
\cline { 2 - 5 } & F.oxysporum & R.solani & M.phaseol & S.rolfsii \\
\hline Mustard seed meal & $2.2 \mathrm{~b}$ & $2 \mathrm{~b}$ & $2 \mathrm{~b}$ & $2.1 \mathrm{c}$ \\
\hline Rhizolex & $2.2 \mathrm{~b}$ & $1.6 \mathrm{c}$ & $2.5 \mathrm{~b}$ & $2.6 \mathrm{~b}$ \\
\hline Infested soil (Control1) & $2.9 \mathrm{a}$ & $4.1 \mathrm{a}$ & $3.8 \mathrm{a}$ & $3.6 \mathrm{a}$ \\
\hline Non-infested soil (control2) & $1.07 \mathrm{a}$ & $1.07 \mathrm{~d}$ & $1.07 \mathrm{c}$ & $1.07 \mathrm{~d}$ \\
\hline LSD & $\cdot .3$ & .34 & $0 . .55$ & 0.46 \\
\hline
\end{tabular}

Figres in the same column followed by the same letters are not significantly different ( $p>$ 0.05 ) based on Duncan's multiple range test

${ }^{\star \star}$ Disease severity of root rot and any discoloration of tissue were recorded according to. Haware and Nene (1980) based on 0-4 scale according percentage of foliage yellowing or necrosis $(0=0 \%, 1=1-33 \%, 2=34-66 \%, 3=67-100 \%, 4=$ dead plant )

Effect of mustard seed meal, and (Rhizolex ${ }^{\circledR)}$ fungicide on shoot weight and plant hieght of soybean plant grown in pathogens infested soil

Data presented in Table (5) revealed that the lowest values of shoot weight and plant height $(18 \mathrm{~g}, 12 \mathrm{~cm} ; 9.6 \mathrm{~g}, 9.8 \mathrm{~cm} ; 8.8 \mathrm{~g}, 10.4 \mathrm{~cm}$; and 12 $\mathrm{g}, 11.5 \mathrm{~cm}$, respectively ) were observed with the control No.1, where soil infested with F.oxysporum, R.solani, M.phaseoli, S.rolfsii without any treatments, while the greatest shoot weight of soybean plants (37.5g plant) was recorded from soybean seedling grown in Rhizoctonia solani- infested soil) and treated with mustard seed meal The same trend was noticed with the other fungi Table (5), mustard seed meal treatment recorded the highest value of shoot weight with all tested fungi except M.phaseoli-infested soil when treated with Rhizolex resulted in slight increase in shoot weight comparing with this value of mustard seed meal treatment. Data in Table (5) also reveal that mustard seed meal treatment recorded the highest value of plant height, with all tested fungi except Rhizoctonia solani- infested-soil when treated with Rhizolex resulted in slight increase in plant height comparing with this value of mustard seed meal treatment.

Table (5): Effect of mustard seed meal, and (Rhizolex ${ }^{\circledR)}$ fungicide on shoot weight and plant hieght of soybean plant grown in pathogens infested soil

\begin{tabular}{|l|c|c|c|c|c|c|c|c|}
\hline Treatments & \multicolumn{6}{|c|}{ Shoot weight and plant height of soybean plant } \\
\hline & F.oxysporum & R.solani & M.phaseoli & S. rolfsii \\
\hline & Sw & Ph & Sw & Ph & Sw & Ph & Sw & Ph \\
\hline mustard seed meal & $34.2 \mathrm{~b}$ & $33.8 \mathrm{~b}$ & $37.5 \mathrm{a}$ & $26 \mathrm{~b}$ & $31.2 \mathrm{~b}$ & $24.4 \mathrm{~b}$ & $35.4 \mathrm{~b}$ & $32 \mathrm{~b}$ \\
\hline Rhizolex $^{\circledR}$ & $22.8 \mathrm{c}$ & $17 \mathrm{c}$ & $33.6 \mathrm{a}$ & $21.6 \mathrm{~b}$ & 32.6 & $23.6 \mathrm{~b}$ & $31.4 \mathrm{~b}$ & $18.4 \mathrm{c}$ \\
\hline Infested soil (Control1) & $18 \mathrm{~d}$ & $12 \mathrm{~b}$ & 9.6 & $9.8 \mathrm{c}$ & $8.8 \mathrm{c}$ & $10.4 \mathrm{c}$ & $12 \mathrm{c}$ & $11.5 \mathrm{~d}$ \\
\hline Non-infested soil (control2) & $39 \mathrm{a}$ & $37.4 \mathrm{a}$ & $39 \mathrm{a}$ & $37.4 \mathrm{a}$ & $39 \mathrm{a}$ & $37.4 \mathrm{a}$ & $39 \mathrm{a}$ & $37.4 \mathrm{a}$ \\
\hline L.S.D. & 2.21 & 5.9 & 2.13 & 5.6 & 2.2 & 5.5 & 2.3 & 4.64 \\
\hline Sw= Shoot weight g/ plant & \multicolumn{6}{|c|}{ Ph } & \multicolumn{7}{|c|}{ Plant height (cm) }
\end{tabular}

Figres in the same column followed by the same letters are not significantly different $(p>$ 0.05 ) based on Duncan's multiple range test 
3-Field experiment:

3.1- Effect of mustard seed meal and one (Rhizolex) fungicide on root rot and wilt diseases complex of chickpea plant under field condition.

The effect of mustard seed meal and Rhizolex on incidence of root rot and wilt of soybean under field is shown in Table (6). The incidence of diseased soybean plants decreased by using mustard seed meal $(23.3 \%)$ followed by Rhizolex (15\%) compared with the control (58.7\%) 4 months after sowing. Significantly differences were realized between control treatment and other treatments, the most effective treatments were recorded from Rhizolex but there is not significantly differences were realized between mustard seed meal and Rhizolex treatment.

Table (6): Effect of mustard seed meal and Rhizolex fungicide on root rot and wilt diseases complex of soybean plant under field condition.

\begin{tabular}{|l|c|c|}
\hline \multirow{2}{*}{ Treatments } & \multicolumn{2}{|c|}{ Incidence (\%) of diseased plants } \\
\cline { 2 - 3 } & \multicolumn{2}{|c|}{ 4 months after sowing } \\
\hline Mustard seed meal & Disease Incidence (\%) & Reduction over control \\
\hline Rhizolex & $23.2^{\mathrm{b}}$ & 69.5 \\
\hline Control & $15^{\mathrm{b}}$ & 74.4 \\
\hline LSD & $58.7^{\mathrm{a}}$ & 0 \\
\hline
\end{tabular}

Figures in the same column followed by the same letters are not significantly different ( $p>$ 0.05 ) based on Duncan's multiple range test

\section{DISCUSSION}

Isolation trails from rotted and wilted soybean plants yielded Fusarium oxysporum, Fusarium solani, Rhizoctonia solani, Macrophomin phasolina and Sclerotum rolfsii conforming with other reports. (Amer, 2005; Bahaa_Eldin, 2005, Luiz et al., 2006, Pabon et al., 2006, Wrather et al., 2007 and Sweets, 2008) found that these pathogens caused in serious economic losses.

Fumigation of soil before planting to control soil-borne diseases and pests of economically important crops has been used in agriculture for many years However; recently the use of chemical fumigants has been reduced for several reasons, including pollution of environment, particularly ground water and food supplies. Recently, an increasing desire to reduce the use of pesticides is seen through the attempts to develop integrated pest management approaches, where natural resources are put to maximum use. However, the use of pesticides will continue but at lower rate, wherever it is necessary. Therefore, it was thought to be of value to use biofumigation in comparison to fungicides to be included in the protection of the crops.

Biofumigation refers to the suppression of soil borne pathogens by volatile biocidal compounds (mainly isothiocyanates (ITCs), released when the glucosinolates in Brassica species as seed meal are hydrolyzed during breakdown in the soil (Cole, 1980; Angua et al., 1994; Noble et al., 2002; Harvey et al., 2002 and Kirkegaard et al., 2006). 
Fayzalla, E.A. et al.

The effect of mustard (Brassica juncea) as a biofumigation was evaluated in laboratory, in the pots and in filed against F.oxysporum, R. solani, M. Phaseolina and S. rolfsii infecting soybean plants.

In the present investigation, mustard seed meal proved to be effective for controlling the causal pathogens of root rot and wilt of soybean plant. It had resulted in decreasing the linear growth of the tested fungi as compared with the control. There were differences in the sensitivity of the pathogens to the seed meal at all levels, R.solani was the most sensitive fungus, it was noticed that the seed meal reduced the linear growth of R.solani at all levels $5 \mathrm{mg}, 10 \mathrm{mg}$ and $25 \mathrm{mg}$ by $54.4 \%, 57.5 \%$ and $76.6 \%$, respectively over the control. Also it showed reduction in the liner growth by $50 \%, 76.6 \%$ and $85.5 \%$ for M. phaseolina, by $42.2 \%, 55.5 \%$ and 63.3 for S. rolfsii and by $54.4 \%, 57.5 \%$ and $76.6 \%$ for F.oxysorum at all levels, respectively. The results are in conformity with those of Noble et al. (2002). Seed meal of Brassica species suppresses the growth of Pythium ultimum, $R$. solani (Charron and Sams, 1999) and Fusarium sambucinum (Mayton et al., 1996). Chung et al. (2002) proved that the volatile substances in the ground seed of mustard (Brassica juncea) showed the strongest fungicidal effect on Rhizoctonia solani during comparing three Brassica species for volatile compounds in hydrated ground seeds. Kirkegaard et al., 2006 found that seed meal of mustard (B. juncea) were fungicidal to five soil-borne pathogens.

In vitro assays, Indian mustard resulting in nearly complete inhibition (80-100\%) of growth of soilborne pathogens of potato, including Rhizoctonia solani, Phytophthora erythroseptica, Pythium ultimum, Sclerotinia sclerotiorum, and Fusarium sambucinam (Robert and Timothy, 2007).

\section{Effects of mustard seed meal on soybean germination and growth were studied.}

The obtained results indicated that up to $40 \mathrm{~kg} / \mathrm{fadane}$ and below at the lowest level of seed meal could be applied with the seed at the time of sowing without reducing germination or seedling growth. There are many reports supporting these results such as Kirkegaard et al., (2006) reported that mustard seed meal was applied with the wheat .Seed had no effect on the germination or growth at rates of $40 \mathrm{~kg} / \mathrm{fadane}$ and below although at the lowest level there was a trend towards increased shoot growth.

Effect of mustard seed meal and Rhizolex fungicide on soybean seedling grown in pot soil infested with some pathogenic fungi was studied. The data from this study showed that soil amendments with seed meal have shown promising results for controlling soil borne pathogens. The results revealed that percentage of healthy plants remaining in the pots, depended on the treatments, it has been found that sufficient control of damping off was obtained by using mustard seed meal and fungicide. Rhizolex showed a good effect but mustard seed meal was superior to all treatments. In non-infested soil, $90 \%$ of the plants were healthy. Treatment mustard or fungicide showed better effect on plant health than untreated when the pathogen was involved. In soil infested with $F$. solani, $R$. solani, $M$. phasolina and S,rolfsii application of seed meal resulted in significant reduction of damping off and increasing 
of healthy plants compared to the infested control. The reduction in diseases reflected on soybean growth parameters. Increases in shoot weight, plant height of plants grown in infested and treated pot were noticed compared with infested and non treated ones. Effects of mustard seed meal on the tested fungi may be due to the biocidal effect principally isothiocyanates (ITCs), released when the glucosinolates in mustard seed meal are hydrolyzed during breakdown in the soil (Angua et al., 1994; Noble et al., 2002 and Kirkegaard et al., 2006. Previous reports supporting these results such as Chung et al. 2002 reported that coating cabbage seeds with MBF mixture $(40 \%$ mustard ground seed in $60 \%$ Biolan peat B3) significantly reduced incidence of Rhizoctonia damping-off and enhanced seedling growth of cabbage. Van Os and Lazzeri, 2006 reported that in soil infested with Rhizoctonia solani, application of seed meal resulted in control of stem infection in lily. And they also found that Percentage of healthy plants was $20 \%$ in the infested control treatment and $60 \%$ in the infested seed meal treatment. The efficacy of seed meal was equal to the chemical treatment with azoxystrobine. Brassicaceae seed meal amendments effectively control Rhizoctonia root rot of apple and suppress weed growth in the soil (Mazzola et al., 2006)

Robert and Timothy (2007) revealed in greenhouse tests that Indian mustard reduced potato seedling disease by $40-83 \%$.

An experiment was planned to study the effect of mustard seed meal comparing with Rhizolex fungicide on wilt and root rot disease complex of chickpea in the field plots. The obtained results indicated that mustard seed meal and Rhizolex treatments reduced the disease incidence by $69.5 \%$ and $74.4 \%$ respectively when recorded 4 months after planting,. There are many reports supporting these results such as Mazzola and Abi Ghanem (2006) they established field trials to evaluate the efficacy of brassicaceae seed meal amendments for control of the soil borne pathogen/parasite complex inciting apple replant disease, and capacity of such treatments to enhance tree growth and yield. They found also that tree growth in $B$. juncea seed meal treated soils has been superior to all other treatments, including preplant soil fumigation.

\section{REFERENCES}

Akande, S. R., Owolade, O.F. and Ayanwole J.A.(2007) Field evaluation of soybean varieties at llorin in the southern guinea savanna ecology of Nigeria.African Journal of Agricultural Research Vol. 2 (8), pp. 356-359, August 2007

Amer M.A. (2005) Reaction of selected soybean cultivars to Rhizoctonia root rot and other damping-off disease agents. Commun Agric Appl Biol Sci. 2005; 70(3):381-90.

Angua,J.F.; P. A. Gardner; J. A. Kirkegaard and J. M. Desmarchelier, 1994 .Biofumigation: Isothiocyanates released from brassica roots inhibit growth of the take-all fungus, Plant Soil, 162, (1): 
Bahaa El-Din ,H.M.(2005) Studies some fungal diseases affected the roots and stem on soybean in Egypt. Faculty of Agriculture Suez Canal university 132pp.

Barnet, H.L. and Hunter B.B., 1986. Illustrated Genera of Imperfect fungi Macmillan Puplishing Company New York.

Booth, C., 1971.The genus Fusarium. CMI, Kew, Surray, England, 237 pp.

Charron, C.S, and S.E. Sams, 1999. Inhibition of Pythium ultimum and Rhizoctonia solani by shredded leaves of Brassica species. Journal American Society of Horticultural Science. 124:462-467.

Chung,W.C. ; J.W.Huang ; H.C.Huang ; and J.F.Jen, 2002.Effect of ground Brassica seed meal on control of Rhizoctonia damping-off of cabbage. Canadian Journal of Plant Pathology 24:211-218.

Cole, R.A. 1980. Volatile components produced during ontogeny of some cultivated crucifers. J. Sci. Food Agric. 31: 549-557.

Duncan, D.B.1955 Multiple range test and multiple $F$ test Biometrices, 1:1-42

Haikal. Z. Nahed (2008) Effect of Filtrates of Pathogenic Fungi of Soybean on Seed Germination and Seedling Parameters. Journal of Applied Sciences Research, 4(1): 48-52, 2008

Harvey, S.G., H.N. Hannahan \& C.E. Sams 2002 Indian mustard and allyl isothiocyanate inhibit Sclerotium rolfsii. Journal American Society of Horticultural Science 127:27-31.

Hashem,M. 2004.Biological control of two pathogenic fungal species isolated from the rizoplane of soybean czech_mycology:56(4/3):238-223

Haware, M.P. and Y.L. Nene 1980 . sources of resistance to wilt and root rot of chickpea .INT Chickpea Newsletter 3:11-12.

Kirkegaard J.A.; P.T.W. Wong, J.M. Desmarchelier and M. Sarwar1 (2006) Suppression of soil-borne cereal pathogens and inhibition of wheat germination by mustard seed Proceedings of the 13th Australian Agronomy Conference,10-15 September 2006,Australian Society of Agronomy.

Lodha, S. And Sharma,S.K. 2002. Effect of natural heating and Brassica amendments on survival of Macrophomina phaseolina. Indian Phytopathology 55:342-344.

Luiz E.; B. Blum; Rodrigo Rodríguez-Kábana ( 2006) .Powders of kudzu, velvetbean, and pine bark added to soil increase microbial population and reduce Southern blight of soybean. Fitopatol. bras. vol.31 no.6, p.551-556. ISSN 0100-4158.

Mawar, R.,S. and S.K. Lodha 2002 Brassica amendments and summer irrigation for control of Macrophomina phaseolina and Fusarium oxysporum f. sp. cumuni in hot arid regions. Phytopathologia Mediterranea 41:45-54.

Mayton, H.S.C., Olivier, S.V., Vaughn, R.L., and Loria, R. 1996.Correlation of fungicide activity of Brassica species with allyl isothiocyanate production in macerated leaf tissue.Phytopathology, 86: 267-271. 
Mazzola, M., 2003. Non-fumigant measures and assessment of host tolerance for replant disease control. In: Proceedings Annual International Research Conference on Methyl Bromide Alternatives and Emissions Reductions. Methyl Bromide Alternatives Outreach, Fresno, CA, pp. 9.1-9.3.

Mazzola,M. and R. Abi Ghanem 2006 Application of brassicaceae seed meals for the management of apple replant disease Second International Biofumigation Symposium University of Idaho, Moscow, June 25 - June 29, 2006

Mazzola,M. , L. Hoagland ,L. Carpenter-Boggs, R.Abi Ghanem and M.Cohen 2006. Contribution of resident soil microorganisms to brassicaceae seed meal-induced disease and weed suppression.. Second International Biofumigation Symposium University of Idaho, Moscow, June 25 - June 29, 2006

Nassiuma D, Wasike W (2002). Stability assessment of soybean varieties in Kenya, Afr. Crop Sci. J 10(2): 139-144

Nelson, S.E., J.A. Toussoun, and W.F.Marasas 1983. Fusarium spp. An illustrated manual for identification. The Pennsylvania State Univ. Press, USA

Noble, R. R. P.; S. G Harvey and C. E. Sams 2002. Toxicity of Indian mustard and allyl isothiocyanate to masked chafer beetle larvae.Online.Plant Health Progress doi:10.1094/PHP-2002-0610-01RS.

Olivier, C., Vaughn, S.F., Mizubuti, E.S.G. \& Loria, R.1999. Variation in allyl isothiocyanate production within Brassica species and correlation with fungicidal activity. Journal of Chemical Ecology 25:2687-2701.

Pabon, A., Hill, C. B., and Hartman, G. L. 2006. Greenhouse methods for screening for resistance to charcoal rot in soybeans. Canada, July 29 August 2, 2006. (2.1MB

Robert, P. Larkin and Timothy S. Griffin 2007 Control of soilborne potato diseases using Brassica green manures. Crop Protection 26 (7): 10671077

Sarwar, M., Kirkegaard, J.A., Wong, P.T.W., and Desmarchelier,J.M. 1998. Biofumigation potential of brassicas. III. In vitro toxicity of isothiocyanates to soil-borne fungal pathogens. Plant Soil, 201: 103112.

Sweets, Laura (2008) Early Season Soybean Diseases. Integrated pest and crop management, Volume 18, Number 12.p82

Toussoun J.A.and S.E.Nelson 1968 Pictorial. Juide to the identificat to Fusarium Species. Pennsylvania State University Prss. University Park. 51PP

Van Os G.J., V. Bijman, A.S. van Bruggen, F.A. de Boer, S. Breeuwsma, J. van der Bent, M. de Boer, L. Lazzeri 2004 Biofumigation against soil borne diseases in flower bulb culture. Agroindustria 3 (3): 285-301

Van Os,G. and L. Lazzeri 2006 Control of Rhizoctonia solani in lily by biofumigation with Brassica seed meal. Second International Biofumigation Symposium University of Idaho, Moscow, June 25 - June 29, 2006 
Fayzalla, E.A. et al.

Wrather, A.J., Shannon, G., Mengistu, A. 2007. Soybean Planting Date Effects On Soil Population Density of Macrophomina. Plant Health Progress

مقاومة بعض الفطريات الممرضة الكامنة فى التربة في نبات فول الصويا بواسطة

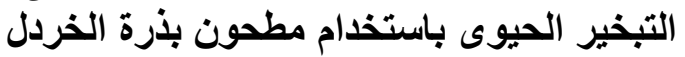

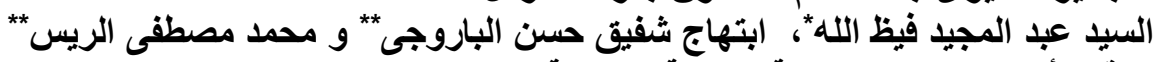

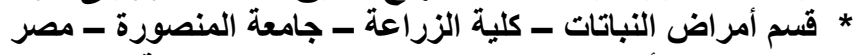

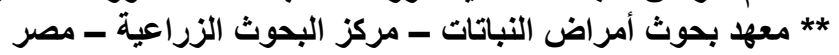

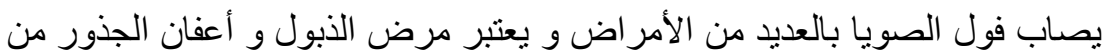

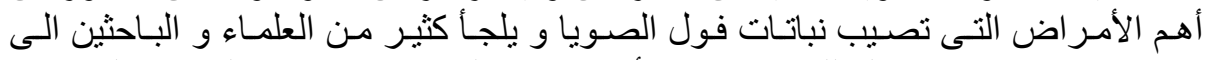

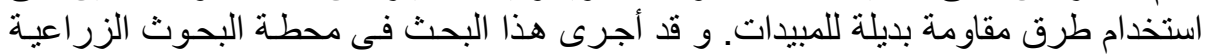

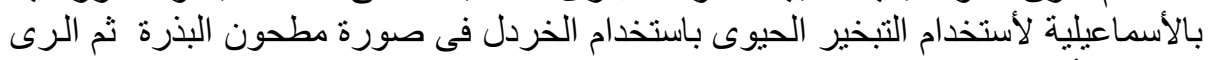

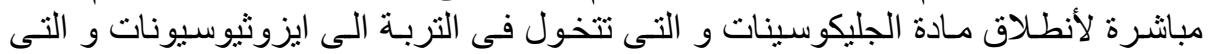

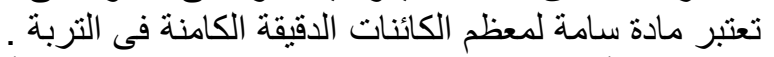

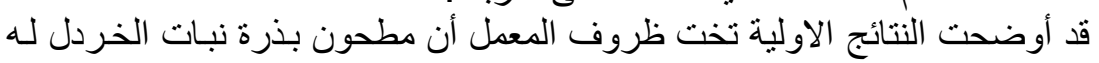

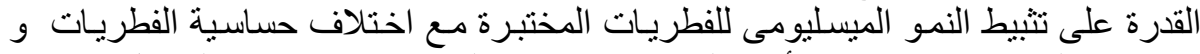

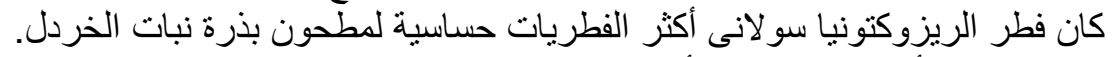

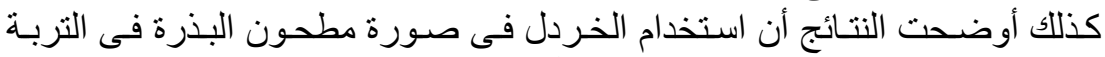

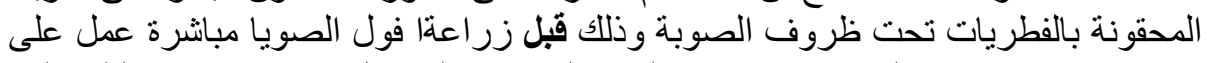

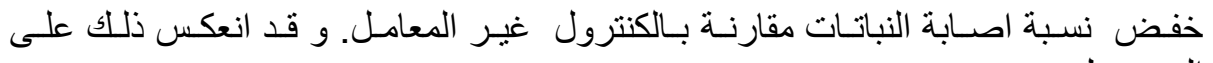
المحصول.

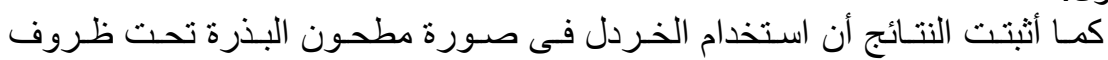

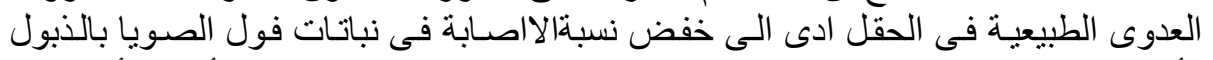

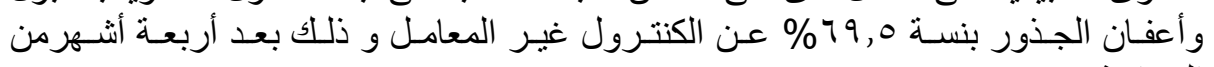

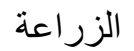

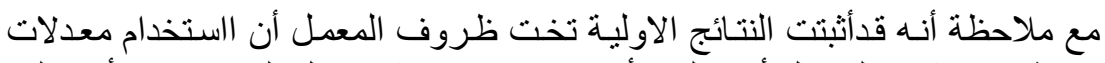

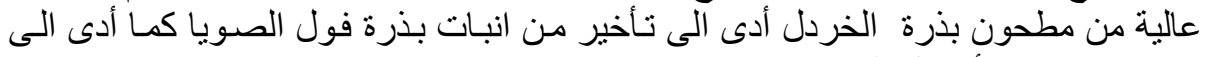

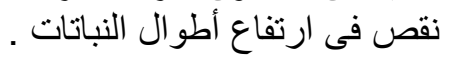

